\title{
Arts Education Within The Mayong Pottery Artisan Families: A Local Art Conservation Strategy
}

\author{
Triyanto $^{\bowtie}$, Syakir, Mujiyono \\ Department of Fine Arts Education, Faculty of Languages and Arts, \\ Universitas Negeri Semarang, Indonesia
}

Received: June 20, 2019. Revised: November 4, 2019. Accepted: December 28, 2019

\begin{abstract}
This study aims to examine the problem of applying the pattern of traditional arts education in the Mayong ceramic artisan family seen as a strategy in conserving local art. This research used a qualitative-ethnographic approach. The research objectives cover aspects of cultural values of dance, human resources, and the environment and their changes that are systemically related functionally in the art education process in the family sphere. Research data were collected through participatory observation techniques, in-depth interviews, and documentation - validation of data through source triangulation and thick description. Data analysis techniques were carried out in an interactive cycle that moves between the processes of reduction, presentation, and verification of data. The results of the study show the following. First, there are cultural values in the culture of the Mayong ceramic artisan family community, which are oriented to the view of the importance of the obligation to inherit their local arts. Second, human resources, cultural values, and the natural environment show the interrelationships in the formation of art education patterns in the family. Third, as a conservation strategy, the pattern of art education that takes place within the family has succeeded in preserving and developing local ceramic arts. Other local art artisan communities can adopt suggestions that can be put forward in this informal art education pattern in efforts to conserve regional cultural heritage.
\end{abstract}

Keywords: Culture; Family; Local Ceramics; Conservation; Arts Education

How to Cite: Triyanto, Syakir, \& Mujiyono. (2019). Arts Education Within The Mayong Pottery Artisan Families: A Local Art Conservation Strategy. Harmonia: Journal of Arts Research And Education, 19(2), 152-162.

\section{INTRODUCTION}

Indonesia, as an archipelagic multicultural and multicultural country, has a unique and diverse local art wealth as a regional cultural heritage. The cultural heritage of this region is a bond and reinforcement of an essential asset of national cultural identity amid the global cultural arena. Art, including crafts and design, is a type of thinking/making that allows people to form and develop their characters
(Chamim et al. (2003) suggested that traditional art is a product of local creativity through intergenerational inheritance that presents cultural symbols. Wolff (1989) suggested that art can be seen as a repository for cultural meanings. In this regard, Caruso (2005) asserts that works of art are cultural and social artistic expressions that contain values. Therefore, its existence is essential to be preserved and developed in accordance with the demands of the times. One of the local arts that need to be conser-

\footnotetext{
${ }^{\square}$ Corresponding author:

E-mail: triyanto@mail.unnes.ac.id
} 
ved is traditional ceramic art.

History shows that ceramics are prehistoric crafts of art. Gopnic (2000) through the results of his research in Iran, showed that ceramics could be used to reconstruct the activities, habits, and behavior of the community, including being used to explain about the arts, beliefs, trade, population distribution, and the level of civilization of society at that time. Yumarta (1982) explains that traditional ceramics in the form of containers have historically been known since humans started to see the culture of farming and settled permanently instead of nomadically. In that era, equipment was needed to store food (Iswidayati, 2009) and for cooking purposes. Sayogyo (1985) shows a fact that indicates that in the life of rural communities, ceramic crafts have a real function both physically as a means to meet the practical needs of everyday households and economically as an alternative source of income for families.

However, the reality shows that along with the ongoing process of modernization, many local traditional arts are marginalized and even experience extinction (Jazuli, 2001; Dahana, 2012). Traditional ceramic art is one of the local arts which experienced outcasting and even experienced extinction (Sidharta, 1991; Iswidayati, 2009). The outcasting and extinction are, in general, due to the artisans are less persistent trying to inherit the next generation, their lack of creativity in the process of adapting, and the change in work orientation of the next generation in modern industries that are more economically promising.

Historically, Mayong Lor Village, located in Mayong District of Jepara, Central Java, has been known for a long time as the center of industrial handicrafts home industry in the form of earthenware/ceramic art (pottery). According to Harjito (2002), the emergence of Mayong Lor's traditional ceramic art is estimated to have existed around the 15th century.

The pottery ceramic home industry has become the pride and identity of the villagers of Mayong Lor village. This ceramic business is also the source of livelihood of the people in descending-hereditary (Karthadinata, 2005; Rahmawati, 2008; Mahbub, 2010). The industry, in general, contributes to the revenue of Jepara Regency (Gusta$\mathrm{mi}, 2000$ ). To date, although the era has undergone changes, the existence of the pottery industry in Mayong village can continue sustainably.

This condition shows that its presence has become an essential cultural capital for the community of the artisans. As stated by Bourdieu (1996), cultural capital is a form of knowledge, skills, education, and benefits that are owned by a person or a group of people and provide status in the community. Parents provide their children with cultural capital; cultural capital has three subtypes, namely: manifested, objectified, and institutionalized.

Following the background above, especially regarding its position and function as cultural capital, this study aimed to examine how the form of informal art education carried out by each family of the ceramic craftsman community in local art conservation so that it could be maintained across generations.

\section{METHODS}

This research used a qualitative-ethnographic approach. The research location was Mayong Lor Village, Jepara Regency, Central Java Province. Research targets included cultural values of the artisans, the realization of the potteries produced along with the functions that accompany them, patterns of informal art education in the form of the process of inheriting knowledge, attitudes, and skills from parents to children of the next generation in conserving the continuity of its cultural culture, and the condition of environmental resources and changes that provide support for the preservation and development of the local ceramics of Mayong Village. Research data were collected using the participant-observation technique, in-depth interviews, and documentation. Data validation was done using the triangulation of 
sources and thick description techniques. Data analysis used interactive cycle techniques that move between the processes of reduction, presentation, and verification, as stated by Miles and Huberman (1991).

\section{RESULTS AND DISCUSSION}

\section{Mayong Lor Village: The Center of Local Ceramic Craft}

Mayong Lor Village, which is part of the Mayong Regency in Jepara, located on the northern side of Central Java province, is located about $24 \mathrm{Km}$ from the district administration center and $68 \mathrm{Km}$ from the provincial capital. Among the four villages inside Mayong Lor Village, Dusun Krajan and Bendowangen are the center areas of the pottery arts industry.

The village archive data shows that the topographical form of the natural environment of Mayong Lor Village is generally a lowland ( 0 meters above sea level) with an average daily temperature of about $33^{\circ} \mathrm{C}$. The condition of the natural environment is a fertile area with slightly reddish-yellow-colored soil. This type of soil is clay, which contains fused silica and fine aluminum. Chemically, according to Astuti (1982), clay is included in the class of pure aluminum hydrosilicate. This type of soil is suitable for making ceramics. The condition of this soil type is clearly a factor that enables and facilitates the production of ceramics in this village. The availability of raw materials from the natural environment itself makes the artisans can freely produce every time.

The available road infrastructure makes transportation facilities easy to obtain both for obtaining raw materials for production and the distribution process; this helps to support the existence and continuous operation of the Mayong Lor Village artisans community.

Historically, the existence of pottery in Mayong Lor Village is estimated to have arisen around the 15th century (Harjito, 2002). The origin of ceramics in Mayong Lor Village cannot be separated from the role of the village's ancestral ancestor,
Kanjeng Ibu Rr. Ayu Mas Semangkin (locally known by her nickname as Ibu Mas) who is a relative of the Sultanate of Demak. An author's resource person, Siwoyo HP, a relative of Kanjeng Mrs. Rr. Ayu Mas Semangkin, said that in developing her hermitage, Ibu Mas fostered residents of the community around her hermitage by giving them life skills to make pottery ceramics. The consideration, at that time, most of the population who worked as rice farmers have wasted their time by being unemployed while waiting for the harvest.

The choice of skill type is based on the reason for the potential of local natural resources to have a type of clay that can be used as raw material for making pottery ceramics. In addition, they can also easily use branches and dried leaves of trees that grow around their place as the fuel; they can also use the waste of rice plants (damen and brambut), which is planted by the population. Over time, the shift in work orientation from farmers to pottery artisans made the majority of Mayong Lor Village residents finally focus their work in the field of ceramic arts (tile, brick, and earthenware) until now through a process of tradition.

To date, 96 family heads are actively pursuing ceramic pottery production activities. Traditional forms of Mayong ceramics (old designs) produced include: jugs, kendil, ketep, cowek, paso, angklo, gentong, padasan, piggy bank, remitan (children's toys), and other creative forms (new designs) (Figures $2 \& 3 a, b, c$ ).

\section{Cultural Values of Pottery within the Ar- tisans' View \\ For the artisans, ceramics are not} only artifacts that have physical and economic value, but also do they have values that are considered valuable in their lives. Historically, its presence, which has lasted for six centuries until now, shows how meaningful its existence is.

If the activities of producing ceramics are merely to fulfill their economic needs, then it is questionable why until now, it can still last for a long time. This 

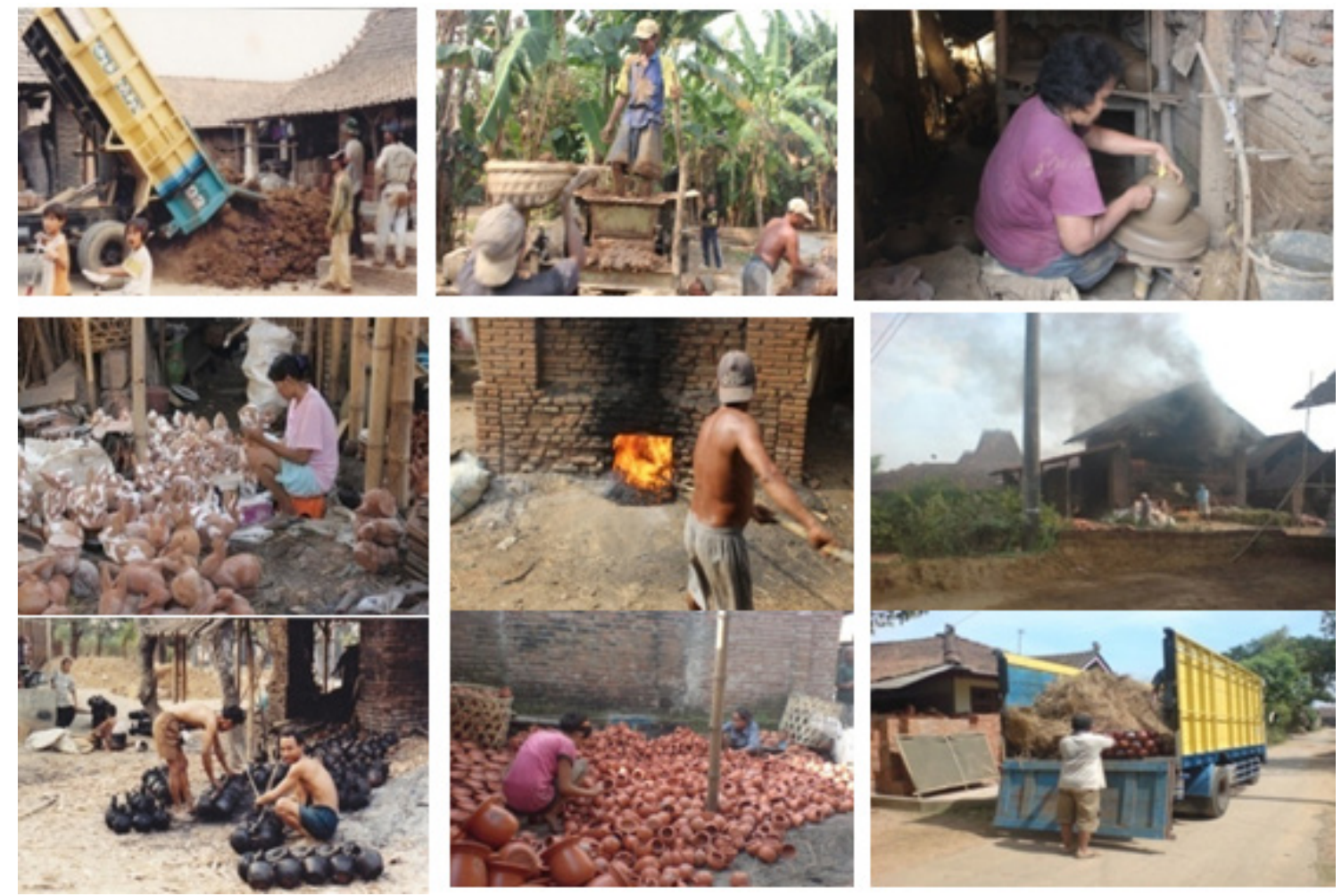

Figure 1. The activity of Mayong Lor Village producing local ceramic art (Author's documentations)

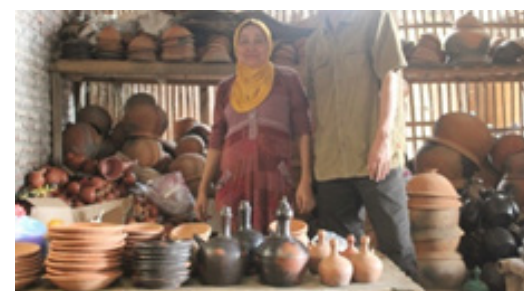

Figure 2a. Traditional pottery ceramics products (Author's documentations)

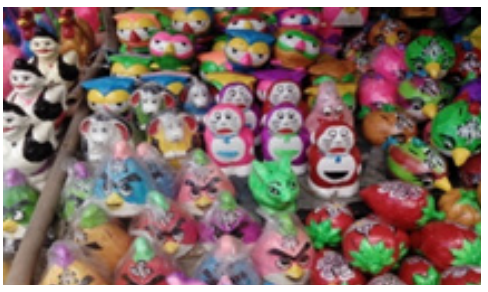

Figure 2b. Ceramic piggy bank products with modern design (Author's documentations)
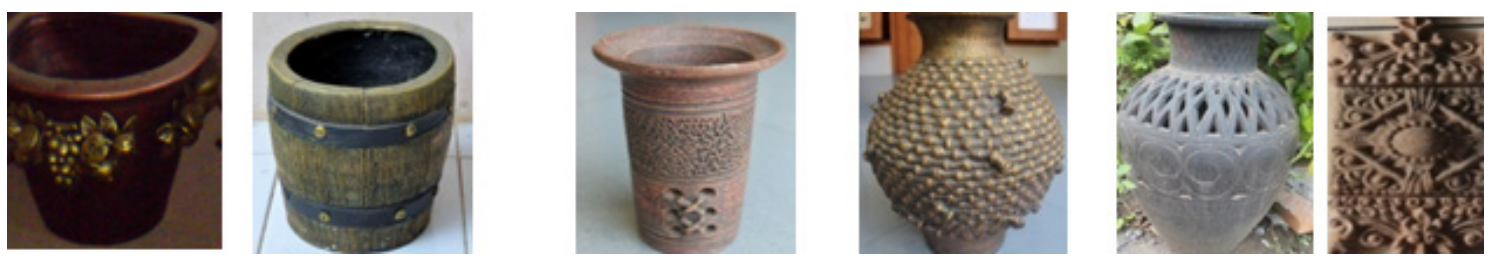

Figure 2c. Development of new creative ceramic forms with new designs (Author's documentations)

question is relevant because if calculated economically, the results of that business do not promise financial benefits that can make them rich. In reality, with the effort to produce ceramics, the life of the artisans shows the conditions of homeliness in various ways.

It can be seen from the daily lifestyle of the artisans in their attitudes that stem from the cultural values of their life orientation. The results of interviews with several artisans obtained the following phrases. "Nrimo ing pandum lan syukur rejeki paringane Gusti Allah," (resignedly accepting and grateful for the sustenance provided by God Almighty). "Urip iku wis tinekdir mula ora usah ngaya, sing penting isa ngibadah marang Gusti Allah," (life is a letter of taqdeer (destiny), then there is no need to over hope, the important thing is to wor- 
ship God Almighty). Working as an artisan is considered as a destiny/fate that needs to be sincerely accepted and grateful for the provision to face God Almighty. Besides, living in this world is only temporary and brief, "urip iku mung mampir ngombe," (life is as short as stopping by to drink), then whatever the situation is, must be accepted. "Menungso iku mung isane ikhtiar, sing nentokke Gusti Allah," (humans can only try their best, it is always God who ends up deciding). These expressions are part of the values that guide and orient the behavior as an artisan.

Besides, life as an artisan is a historical mandate of parental inheritance that must be carried out by children. In the artisans' cultural system, there is a belief that the mandate of the ancestors/parents to continue the effort to make ceramic crafts must be passed on to their children and grandchildren. Inheritance of ceramic making skills from parents must be looked after (cared for/nurtured) and put in the hands (upheld) by children as the next generation to be maintained and continued. In this belief, children can be kualat (subject to a kind of curse) if they ignore the mandate.

\section{Ceramic Arts Education within the Fam- ily: A Conservation Strategy}

Traditional ceramic art, as one form of local cultural creativity in Boudieuan's perspective, can be categorized as cultural capital. Bordieu (1996) explains that cultural capital is knowledge, skills, education, and benefits that are owned by a person or group of people who give status in society. Parents provide their children with cultural capital. Cultural capital has three subtypes; manifested, objectified, and institutionalized (Bourdieu, 1996). These three subtypes of cultural capital, according to Bourdieu, have the following differences.

Cultural capital is obtained through non-genetic inheritance that is received from time to time, through learning in the family. Cultural capital is not inherited instantly, but it is obtained from time to time by someone as a habitus. Objective cultural capital includes physical objects such as artworks. Cultural goods can be functioned as commodities and for "symbolic" purposes (Babcock, 1989). Institutionalized cultural capital is community recognition. Hence, this community recognition plays an important role in the labor market; therefore, it is providing opportunities for cultural capital to be produced. Institutional recognition facilitates the conversion of cultural capital into economic capital.

As a result of local cultural creativity, traditional ceramics contain these three types of cultural capital. Traditional ceramics are the result of inheriting knowledge, values, and skills through a learning process that is not a genetic inheritance. Its presence is a visual language that functions as a field of communication between supporters to meet the primary needs, social, and integrative life. Traditional art is objectified in the form of works of art that have aesthetic value and economic value in the sense of being a commodity of traded art. Traditional art can be categorized as an institutionalized cultural capital because of its existence as a system of values and social institutions as norms in the attitude and behavior of its citizens.

As a cultural capital, pottery in the artisan community has three functions. Firstly, the primary function, crafting activities are an effort to obtain a salary to meet the daily needs of their modest life. Secondly, social function, the activities of crafting become the communication field and fellow interactions between artisans to help each other, build cooperation, and living as fellow artisans. This function, latently, becomes a means to maintain community cohesion and social integration. Thirdly, integrative function, crafting activities function as a means of meeting the needs of aesthetic expression and culturally as a historical need to carry out the educational obligations (inheritance) from parents to children as their successors. These functions are the reason why crafting activities can still survive and take place across generations. 
Besides being a mandate from parents, life sustainability guarantee obtained through the crafting activity makes the craftsmen, culturally, need to pass on to their children. Efforts to realize the fulfillment of these needs then implemented through informal education in the family by educating children to have the knowledge, attitudes, production skills, and character values, including responsibility, discipline, patience, accuracy, diligence, cooperation, creativity, and beauty. With this learning, each artisan family transmitted their knowledge, attitudes, skills, and character values to their respective children.

The implementation of informal education, in the perspective of art education, is an embodiment of a conservation strategy to continue to preserve and develop the activities of their children. Therefore, the pattern of the educational process can be stated as a civilizing system.

\section{Mayong Civilization System: An Art Ed- ucation Pattern within the Family.}

The process of civilization or enculturation (Koentjaraningrat, 1986; Kodiran, 2004), is essentially a form of education. If viewed from a cultural perspective, education is a cultural process, which is an effort to transfer, inherit, maintain or continue the knowledge, values, beliefs, and cultural skills through the process of interaction between educators (learning resources) and students (teaching subjects). This process occurs whether intentional or not, consciously or unconsciously, and takes place in the entire structure of human life both in the individual and social spheres in a particular community environment (Rohidi, et al. 1994). In that process, civilization takes place through processes of socialization, transmission, and internalization among generations, so the culture that is considered meaningful to a group of people can be owned, maintained, and passed on by the next generation.

In discussing the education problem in craftsmanship as a cultural process, especially within the scope of the artisans' family, several elements need to be analyzed in the relationship of functional relations as a system systematically. The elements that are intended, at least, include elements of educators (learning resources), students (teaching subjects), goals, approaches or methods used (methods), knowledge, cultural values transferred (material), and patterns of interaction (the relationship between educators and their study subjects). Based on this, the results of the study regarding the informal pattern of education in the artisans' families are presented as follows.

\section{The Element of Educators}

In the family structure of the Mayong Lor ceramic artisans community, older family members occupy the status and role that determines the pattern of family life. In this structure, the older family members are positioned as figures who must be respected and whose instructions, advice, attitudes, and behavior must be followed. In relation to the subject of students (children), the older members of the family are meant to be fathers, mothers, and sisters. Whereas the "significant others" are the older people in the extended family, namely grandparents, uncles, and aunties.

In the artisans' family structure, the older family members function as educators or learning resource for the younger family members. Without being asked, they are either intentional or not, acting like a teacher who provides guidance, examples, instructions, advice, or other directives to grandchildren, children, nieces, or younger siblings who are still in the stage of learning to make ceramics.

The presence of parents or significant others for students or children is very important for their learning process. The artisans who currently exist, when they were children, they learned craftmanship from their mother and father. The same thing is experienced by children today as the next generation; they are studying craftsmanship, helping the work of their parents. The parents with their unique method which will be discussed more specifically 
in the elements of the approach/method, provide a condition of learning informally (kinship) during the process of working through utterances, other technical instructions intimately and full of patience and affection.

\section{The Element of Children (Teaching Sub- ject)}

The teaching subject education in the context of craftsmanship education in the environment of the Mayong Lor Village crafters family is one of the main elements which is being targeted and hoped of beneficiaries of the heritage inheritance. The subjects are the next generations, who are expected to be able to maintain and continue the efforts of the family to craft ceramics.

The subjects here are meant to be the children of each artisan family. These children from an early age, which is at the time when they have entered elementary school age, have been accustomed used to getting involved in helping ceramic production activities that are carried out by their parents in their homes. Girls are accustomed to assisting their mothers to work, especially, mbubut work (making ceramics with turntable techniques). Meanwhile, the boys help the fatherss work, which is processing the soil, burning ceramics, and finishing. The children, after school, immediately assisted their parents> work without being asked. At this elementary school age, children practice doing what is usually done by their parents. Entering junior high/high school age or teenagers, usually, these children already have reliable skills; therefore, they can be released to work alone without having to be often guided directly with technical matters.

As teaching subjects, children learn while working with their parents. It was all done because of their awareness that helping parents is an obligation and, at the same time, a sign of respect and filial piety to their parents.

\section{The Purpose of Ceramic Education in the Family}

Education as a learning process has an important element that is the main target, namely, the goal. The goal element becomes important because it is the orientation for what needs to be taken when the education process takes place. Likewise, the education of craftsmanship in the artisans family in Mayong Lor has a certain purpose, even though this is implicit and natural. Based on the results of interviews and observations, elements of intended educational goals are as follows.

There are two main objectives in the organization of the education process of craftsmanship in the artisan family, namely: (1) providing skills to children as working capital, and (2) making craftsmanship as a cultural heritage that needs to be preserved, maintained, and continued by the next generation in the future. The first goal is short term, while the second goal is a long-term goal.

In the realm of short-term goals, the process of craftsmanship education in the family clearly shows the willingness of artisans as parents to involve their children in the production process so that they take advantage of their free time after returning from school to help parents work as a learning media. Through this process, children are expected to learn the knowledge, attitudes, and skills of the production process directly through the learning process while working.

In addition, along with the process, parents can indirectly form the attitude of children to be able to appreciate a job and be a disciplined, responsible, cooperative, patient, determined, and cautious person. This is felt to be very important for the development and growth of a child's soul towards maturity. For parents, in the long term, the process of learning to children is considered as an opportunity to train children to be independent that can be used as provisions or working capital in the future. 


\section{Methods of Ceramic Education in the Family}

In the context of artisans' family education, the process of delivery, transfer, inheritance, and acceptance of values between parents as educators and children takes place informally in real situations, namely in daily production activities at home. In this way, parents, unwittingly, present an actual context of production activities that give a push to the child to face and experience it through the process of learning while working.

In this way, parents teach everything related to the context of craftsmanship in a "natural way" through the creation of conditions for daily production activities related to their primary work as artisans to their children. Children as students receive what is given by their parents through hands-on training practices in the production process. Although the process that occurs is informal, however, the learning approach or model still shows the existence of a typical patterned method.

A method is a way that serves as a tool to achieve a goal. Although it is informal, based on observations, it appears that the methods used in the process of craftsmanship education in the environment of the craftsmanship community are very effective in preparing new cadres of artisans. From the observations, the artisans who acted as educators were seen using three main methods, namely the method of habituation, imitation, and appreciation.

The habituation method in the process of craftsmanship education is a way to bring children to see, know, like, and try to work through the process of work training in daily life. By parents, children from childhood are accustomed to the familiar working conditions of their parents. Even when they were still under five, mothers looked after their children while working. In a mother's or father's sling or swing, children are accustomed to seeing and even playing with their parents' works.

The next habit is that children are conditioned to help their parents' work after school by providing types of work from simple (easy) to complex (difficult) levels according to the development of their age. It is in the process of habituation that children learn to see, recognize, know, absorb, and practice doing what their parents do. Because the habituation method takes place continuously in a relatively long time that is from an early age until the child can take care of himself, eventually forms an attitude and pattern of behavior of children who are directed in a pattern or lifestyle as a craftsman.

Another method that is used in an integrated manner in the learning of craftsmanship to children by crafters' parents is the imitation method. In this method, parents unknowingly set an example or role model that children will imitate. In its implementation, in the stages of learning, the children are given a direct example of how they should know and use tools to process a job. But in the next stage, the children only have to follow the example.

Finally, the deepening method or internalization is realized in an integrated manner with two methods of habituation and imitation, namely the inculcation of cultural values that enable the children to live with or incorporate what is learned into them. Figure 4 below shows the informal learning activities.

\section{Inherited Ceramic Culture Values}

From the knowledge aspect, various complexity related to issues of tools, materials, and techniques is introduced by parents to children informally while working. By seeing firsthand the types of tools and materials, as well as the techniques for its usage, they learn to know and gain knowledge about it. Children can immediately see the various equipment used and try to use it themselves.

Second, viewed from the attitude aspect, there are hope and desire from parents to form an independent attitude toward their children. The independence values were instilled since childhood by getting children used to practice helping parents work. According to their developmental age, children are trained to help in 

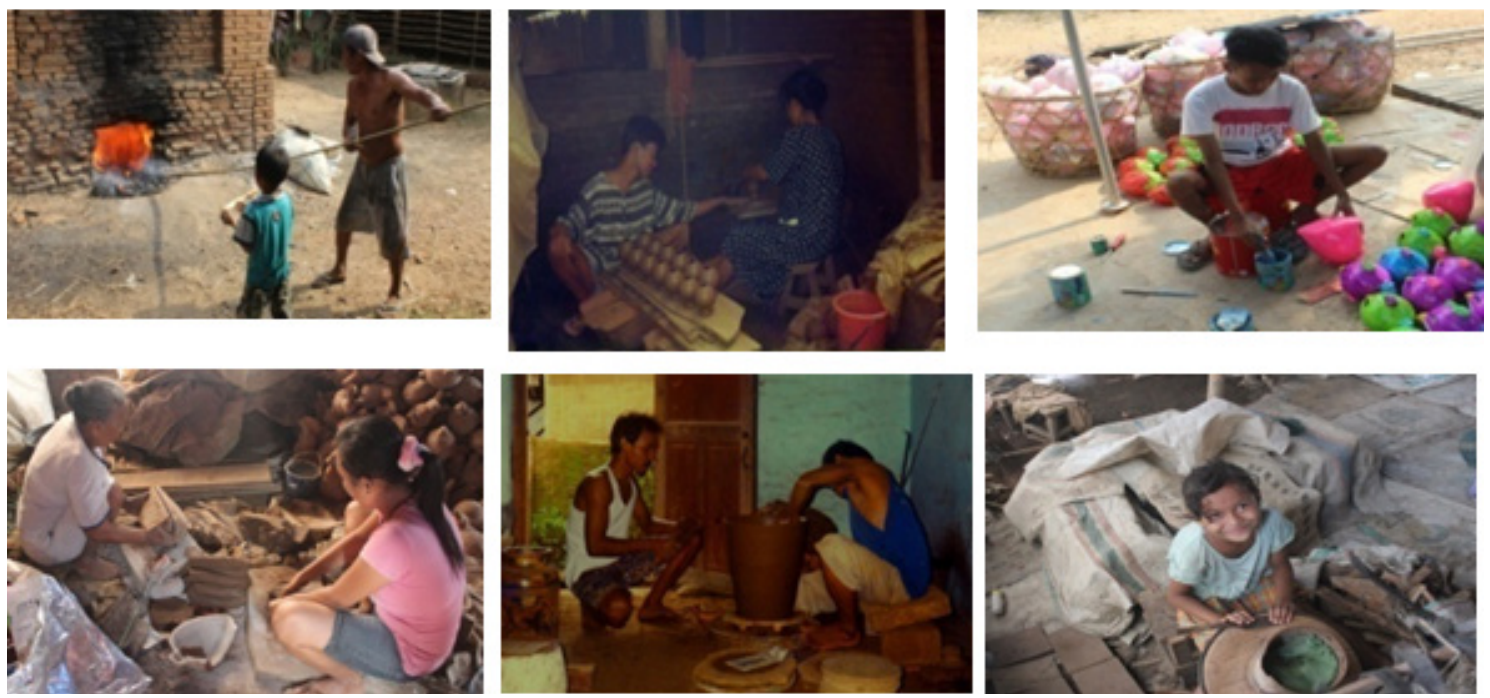

Figure 3. Pictures of ceramic learning activities in the artisans' family environment Author's documentation

the production process. They have been trained informally in discipline, patience, perseverance, caution, care, and responsibility for what should and should not be done.

Established artisans can exemplify the values of diligence, discipline, patience, caution, care, and responsibility that are instilled to form an independent attitude. As soon as they end their bachelor years and live in their household, they can immediately do crafting business to fulfill their family needs. Through the process of craftsmanship education within the fami$\mathrm{ly}$, too, the values of obedience to parents can indirectly be instilled in the artisans' children. The inculcation of these values can form an attitude of respect for parents; it is evidenced by the continuation of the inheritance of crafting skills from their parents until the present day. Other values that are instilled through the enculturation process are efforts to foster cultural awareness to respect the inheritance of the traditions of their ancestor. The value of the work skills possessed by children or artisans nowadays is the result of long training skills that have been carried out. In other words, the process of inheritance of craftsmanship is inherently seen as a form of creative education. At least by referring to Taylor's opinion (Wilson, 2014), creative education leads to the level of productive creativity that is the ability to create a product.

\section{Interaction of the Process of Ceramic En- culturation in the Family}

In the context of artisans' family education, interactions that occur do not look like interactions between teachers and students in formal classes. Psychological boundaries due to differences in status do not affect the mutual relationship between family members in the "teaching" and "learning" processes.

The pattern of interactions that occur in the artisans' family education process is familial. The father, the mother, or other family members who act as educators, do not feel like a teacher. They feel more like parents who have to care. Oppositely, children do not feel as students but rather as children who must respect and imitate the attitudes and behavior of their parents.

With such interaction patterns, an atmosphere of asah, asih, asuh (mutual, compassion, and care) emerges by itself. Both parents and children feel in a position of equal relations.

\section{Chart of Ceramic Arts Education Patterns in Artisan Families}

Based on the explanation above, it can be seen that the informal education processes, as stated above, are a mechanism for 


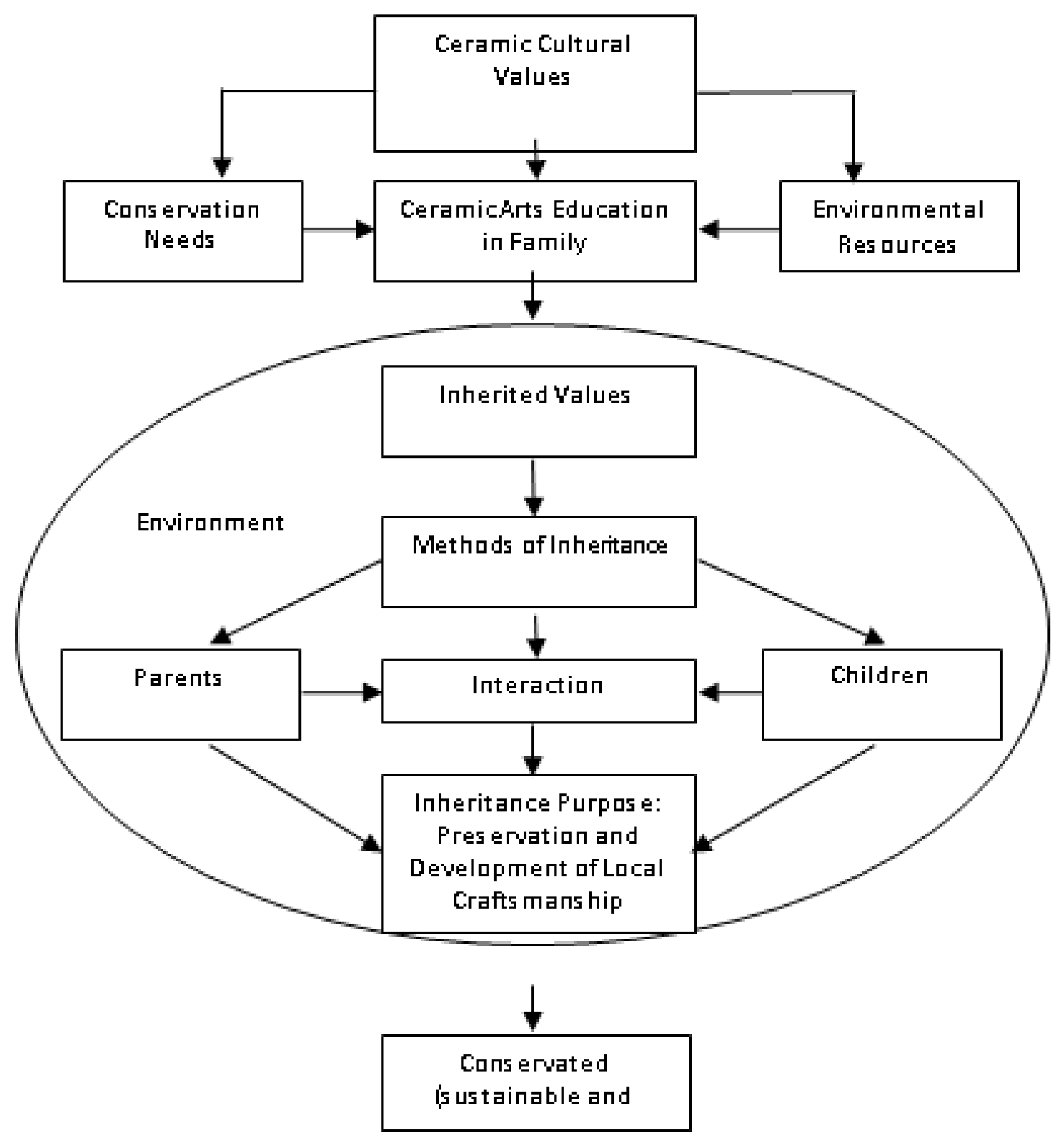

Figure 5. Chart of Local Ceramic Education Patterns in Artisan Families

the realization of a local art conservation strategy. Figure 5 is an abstraction of the pattern of art education in families in the form of a schematic model.

\section{CONCLUSION}

Based on the results of research and discussion, conclusions can be made as follows. First, there are cultural values that are the orientation of the artisans' life-perspective to continue to conserve the continuity of the local crafting arts business from time to time across generations.
Furthermore, in the artisans' community, there is a belief in the cultural system that requires parents to continue, maintain, and carry on the inheritance of the crafting skills of their ancestors to their children and grandchildren. This mandate must be respected and upheld by every family to be carried out. Second, natural, social, and cultural environmental resources provide opportunities for the sustainability of this local ceramic business. Third, to realize these values, each family develops art education in the form of enculturation as a strategic mechanism in realizing the goal 
of conserving their local arts through habituation, imitation, and appreciation or internalization through learning while working.

\section{REFERENCES}

Astuti, A. (1994). Ilmu Pengetahuan Keramik. Yogyakarta: Gajah Mada University Press.

Babcoc, B.A. (1989). At Home, Now Womens Are Storyteller: Ceramic Creativity and and the Politics of Discource in Cohiti Pueblo, in: Lavie, S.(eds.). Creativity/Anthropology. Ithaca and London: Cornell University Press.

Bourdieu, P. (1996). The Forms of Capital. in: J.Richardson (ed). Handbook of Theory and Research for the Sociology of Education. New York: Greenwood.

Caruso, H. Y. C. (2005). Art as a Political Act: Expression of Cultural Identity, Self-Identity, and Gender by Suk Nam Yun and Yong Soon Min. The Journal of Aesthetic Education, 39(3), 71-87.

Chamim, A. I. (2003). Purifikasi dan Reproduksi Budaya di Pantai Utara Jawa. Kartasura Surakarta: Pusat Studi Budaya dan Perubahan Sosial Universitas Muhammadiyah Surakarta.

Dahana, R. P. (January 2013). Forum Kebudayaan Dunia. Jakarta: Kompas.

Gopnik, H. (2000). The Ceramic of Godin II: Ceramic Variability in the Archeological Record, Ph.D. Dissertation, Departement of Near an Middle Eastern Civilizations, Univesity Toronto, Canada.

Gustami, S. P. (2014). Craft Arts and Tourism in Ceramic Art Village of Kasongan in Yogyakarta. Journal of Arts $\mathcal{E}$ Humanities, 3(2), 37- 49.

Harjito. (2002). Mengungkap Silsilah dan Asal-usul Rr. Ayu Mas Semangkin (Kanjeng Ibu Mas) Nimas Ayu Pamikatsih. Himpunan Naskah. Maret Edition, 2002, Mayong Lor Village, Jepara.

Iswidayati, S. (2009). Seni Keramik Nusantara: Dilematis antara Upaya Peles- tarian dan Tuntutan Pasar. Research Report. LP2M Unnes.

Jazuli, M. (2001). Paradigma Seni Pertunjukan Rakyat: Sebuah Wacana Seni Tari, Wayang, dan Seniman. Yogyakarta: Yayasan Lentera Budaya

Karthadinata, D. M. (2005). Studi tentang Pengembangan Desain Kerajinan Keramik Desa mayong Lor. Imajinasi, Jurnal Seni, 1(2), 1-7.

Kayam, U. (1981). Seni, Tradisi, Masyarakat. Jakarta: Sinar Harapan.

Kodiran. (2004). Pewarisan Budaya dan Kepribadian. Humaniora, 16,(1) 1016.

Koentjaraningrat. (1986). Pengantar Ilmu Antropologi. Jakarta: Bina Aksara.

Mahbub, J. (2010). Perkembangan Industri Kerajinan Keramik dan Peranannya terhadap Kehidupan Sosial Ekonomi Masyarakat Desa Mayong Lor Jepara Tahun 1980-2005. Thesis of Study of History.

Miles, M. B \& Hubermen, A.M. (1992). Analisis Data Kualitatif. Terjemahan: T.R. Rohidi. Jakarta: UI. Press.

Rahmawati, D. N. (2008). Kerajinan Keramik: Gerabah Desa Mayong Lor Kecamatan Mayong Kabupaten Jepara. Thesis of Fine Art, Universitas Negeri Semarang.

Rohidi, T. R. (1994). Pendekatan Sistem Sosial Budaya dalam Pendidikan. Semarang: IKIP Semarang Press.

Sayogyo, P. (1985). Peranan Wanita dalam Perkembangan Masyarakat Desa. Jakarta: C.V. Rajawali.

Sidharta, H. (1991). Seni Keramik Modern dalam Perjalanan Seni Rupa Indonesia. Bandung: Penerbit Panitia KIAS,

Wolff, J. (1989). The Social Production of Art. New York: New York University Press.

Yumarta, K. (1982). Keramik. Bandung : Angkasa.

Wilson, L.O. (2014). "There Are Five Distinctive Levels of Personal Creativity-How Are You and Others"? Exploring Cultural Identities through Art. Retrieved from http:/ / theseconprinciple.com/creativity/creativetraits/ levels-of-creativity, 